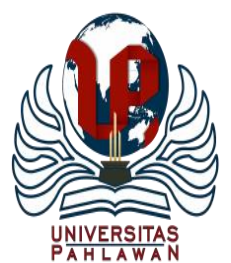

Edukatif : Jurnal Ilmu Pendidikan Volume 3 Nomor 4 Tahun 2021 Halm 1428 - 1436

EDUKATIF: JURNAL ILMU PENDIDIKAN

Research \& Learning in Education

https://edukatif.org/index.php/edukatif/index

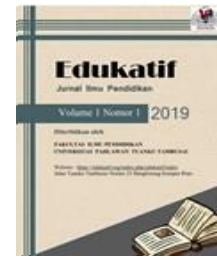

\title{
Pengaruh Manajemen Kelas Dan Etos Kerja Terhadap Efektivitas Pembelajaran Guru Pada Masa Pandemi Covid 19
}

\author{
Pitriyani $^{凶}$ \\ Magister Manajemen Pendidikan, Universitas Jambi, Indonesia \\ E-mail : yanipitri0@gmail.com.id
}

\begin{abstract}
Abstrak
Tujuan penelitian yaitu melihat pengaruh manajemen kelas dan etos kerja terhadap efektivitas pembelajaran di Sekolah Dasar Negeri Kecamatan Jambi Luar Kota. Pendekatan penelitian yaitu kuantitatif. Rancangan penelitian yaitu survey dalam bentuk survey deskriptif. Anggota populasi yaitu keseluruhan guru kecamatan Jambi Luar Kota. Pengambilan Sampel mengunakan Teknik Probability sampling. Data dilakukan melalui kuesioner, memakai skala likert kisaran 1-5. Hasil penelitian menunjukkan manajemen kelas berpengaruh dan signifikan terhadap efektivitas pembelajaran di Sekolah Dasar Negeri Kecamatan Jambi Luar Kota. Nilai signifikansi manajemen kelas $0.00<0.05$ dan nilai ttabel $9.023>1.972$. Etos kerja berpengaruh dan signifikan terhadap efektivitas pembelajaran di Sekolah Dasar Negeri Kecamatan Jambi Luar Kota. Nilai signifikansi etos kerja $0.003<0.05$ dan nilai ttabel $3.007>1.972$. Manajemen kelas dan etos kerja secara bersamaan berpengaruh signifikan terhadap efektivitas pembelajaran di Sekolah Dasar Negeri Kecamatan Jambi Luar Kota. Nilai Fhitung > nilai Ftabel atau $5.169>3.04$ dan tingkat signifikan $0.007<0.05$.
\end{abstract}

Kata kunci : Manajemen Kelas, Etos Kerja dan Efektivitas Pembelajaran

\begin{abstract}
The purpose of the study was to see the effect of classroom management and work ethic on the effectiveness of learning in State Elementary Schools, Jambi Outer City District. The research approach is quantitative. The research design is a survey in the form of a descriptive survey. Members of the population are all teachers of the Jambi Outer City sub-district. Sampling using probability sampling technique. Data was collected through a questionnaire, using a Likert scale ranging from 1-5. The results showed that classroom management had a significant and significant effect on the effectiveness of learning in State Elementary Schools in Jambi Outer City District. The significance value of class management is $0.00<0.05$ and the ttable value is 9.023 > 1.972. Work ethic has a significant and significant effect on the effectiveness of learning in State Elementary Schools in Jambi Outer City District. The significance value of work ethic is $0.003<0.05$ and the ttable value is 3.007 > 1.972. Class management and work ethic simultaneously have a significant effect on the effectiveness of learning in State Elementary Schools in Jambi Outer City District. Fcount > Ftable value or $5.169>3.04$ and significant level $0.007<0.05$.
\end{abstract}

Keywords: Classroom Management, Work Ethic and Learning Effectiveness

Copyright (c) 2021 Pitriyani

$\triangle$ Corresponding author:

Email : yanipitri@gmail.com

DOI : https://doi.org/10.31004/edukatif.v3i4.587

ISSN 2656-8063 (Media Cetak)

ISSN 2656-8071 (Media Online)

Edukatif : Jurnal Ilmu Pendidikan Vol 3 No 4 Tahun 2021 p-ISSN 2656-8063 e-ISSN 2656-8071 
1429 Pengaruh Manajemen Kelas Dan Etos Kerja Terhadap Efektivitas Pembelajaran Guru Pada Masa Pandemi Covid 19 - Pitriyani

DOI: https://doi.org/10.31004/edukatif.v3i4.587

\section{PENDAHULUAN}

Pendidikan di Indonesia memiliki tujuan untuk memberikan pengetahuan, pemahaman, serta pengajaran. Pernyataan tersebut tertuang dalam undang-undang No. 20 tahun 2003 Bab 1 Pasal 1 tentang Sistem Pendidikan Nasional, yang menyebutkan bahwa pendidikan adalah usaha sadar dan terencana untuk mewujudkan suasana belajar dan proses pembelajaran agar peserta didik secara aktif mengembangkan dirinya untuk memiliki kekuatan spiritual keagamaan, pengendalian diri, kepribadian kecerdasan, akhlak mulia, serta keterampilan yang diperlukan dirinya, masyarakat bangsa dan Negara. Pendidikan merupakan investasi penting yang menentukan masa depan bangsa (Pebrianto, Herpratiwi, \& Fitriawan, 2021) Menurut (Suyono, 2012) menjelaskan bahwa efektivitas pada dasarnya merupakan pencapaian hasil yang sesuai dengan tujuan seperti yang telah ditetapkan. Efektivitas berfokus pada hasil program atau kegiatan yang dinilai efektif apabila yang dihasilkan dapat memenuhi tujuan yang diharapkan. Menurut Wotruba dan Wright (Nurlina, 2010)) indikator yang dapat digunakan untuk menentukan efektivitas dalam proses pembelajaran adalah pengorganisasian materi yang baik, komunikasi yang efektif, penguasaan dan antusiasme terhadap materi pelajaran, sikap positif terhadap siswa, pemberian nilai yang adil, keluwesan dalam pendekatan pembelajaran, dan hasil belajar siswa yang baik.

Proses pembelajaran saat ini berlangsung secara efektif dengan adanya interaksi sosial yang terjadi antara guru dan peserta didik, guru dan guru bahkan peserta didik dan peserta didik lain (Farel, Ambiyar, Simatupang, Giatman, \& Syahril, 2021). Kelemahan guru di SDN di Kecamatan Jambi Luar Kota yaitu guru kurang efektif dalam pembelajaran di dalam kelas. Salah satu penyebabnya adalah tidak adanya tujuan pembelajaran yang jelas sebelum kegiatan pembelajaran dilaksanakan. Hal ini menyebabkan peserta didik dan pendidik tidak tahu tujuan apa yang akan dihasilkan sehingga tidak mempunyai gambaran yang jelas dalam proses pembelajaran. Dalam proses pembelajaran diharapkan guru dan siswa memahami setiap tujuan pembelajaran yang akan dicapai. Terlebih bagi seorang guru, karena gurulah yang akan menjadi panutan siswa-siswanya. Pembelajaran yang efektif akan membuat suasana dalam kelas menadi menyenangkan dan pembelajaran mencapai tujuannya.

Kenyataan yang terjadi di lapangan pada guru SDN di kecamatan Jambi Luar Kota yaitu kurangnya keterampilan dalam mengembangkan pengajaran, kesulitan menciptakan pengelolaan kelas yang kondusif sehingga berdampak negatif pada proses pembelajaran dan sulitnya tercapai tujuan pembelajaran dibuktikan dengan kurang giat dan asyik siswa belajar dengan penuh perhatian mendengarkan penjelasan dari guru yang sedang memberikan bahan pelajaran, banyak siswa yang sibuk sendiri dan gaduh saat guru menyampaikan materi pelajaran.

Efektivitas pembelajaran sangat berhubungan erat dengan pengelolaan kelas. Pengelolaan kelas bertujuan agar setiap anak dikelas dapat bekerja dengan tertib sehingga segera tercapai tujuan pengajaran secara efektif dan efesien. Menurut Harsey (Nurlina, 2010) fungsi manajemen kelas maksudnya ialah segala bentuk baik itu berupa perencanaan (planning), pengorganisasian (organizing), pelaksanaan (actuating), dan evaluasi (evaluation). Pengelolaan kelas yang baik akan menimbulkan efektivitas pembelajaran yang baik pula. Maupun sebaliknya jika pembelajaran dikelas tidak efektif maka terdapat kendala-kendala salah satunnya adalah pengelolaan kelas.

Keberhasilan pendidikan bisa di lihat dari proses pembelajaran itu berlangsung, bagaimana guru mampu mengelola kelas dengan baik agar proses pembelajaran berjalan efektif, dan mampu memajukan ataumewujudkan tujuan pendidikan. Menurut (Wiyani \& Ardy, 2013) manajemen kelas ialah aktivitas memadukan sumber-sumber pendidikan agar terpusat untuk kepentingan belajar kelas itu agar hasil belajar yang optimal dapat dicapai. Adapun Menurut Maman Rachman (Djabidi, 2017) menyebutkan" Masalah yang dihadapi guru, baik pemula maupun yang sudah berpengalaman adalah pengelolaan kelas. Aspek yang sering didiskusikan oleh pengajar adalah juga pengelolaan kelas". Mengingat tugas utama dan paling sulit bagi 
1430 Pengaruh Manajemen Kelas Dan Etos Kerja Terhadap Efektivitas Pembelajaran Guru Pada Masa Pandemi Covid 19 - Pitriyani

DOI: https://doi.org/10.31004/edukatif.v3i4.587

pengajar adalah pengelolaan kelas, sedangkan tidak ada satu pendekatan yang dikatakan paling baik. Sebagian besar guru kurang mampu membedakan masalah pengajaran dan masalah pengelolaan. Masalah pengajaran harus diatasi dengan cara pengajaran dan masalah pengelolaan harus diatasi dengan cara pengelolaan.

Manajemen kelas diperlukan karena dari hari ke hari bahkan dari waktu ke waktu tingkah laku dan perbuatan siswa selalu berubah. Hari ini siswa dapat belajar dengan baik dan tenang, tetapi besok belum tentu. Kemarin terjadi persaingan yang sehat dalam kelompok, sebaliknya dimasa mendatang boleh jadi persaingan itu kurang sehat. Kelas selalu dinamis dalam bentuk perilaku, perbuatan, sikap, mental, dan emosional siswa. Karena guru sebagai ujung tombak pelaku pendidikan mempunyai posisi strategis, mempunyai pengaruh langsung terhadap proses pembelajaran. Kualitas proses dan hasil belajar pada akhirnya ditentukan oleh mutu pertemuan antara guru dan siswa. Ilmu guru baik empirik maupun rasional serta berbagai keterampilan yang dimilikinya akan diteruskan dan jadi alat pengembangan sikap keilmuan siswanya (Emmer, 2011)

Kemampuan untuk memanajemen kelas yang ada pada masing-masing individu, tidak terlepas dari etos kerja yang diyakini oleh individu-individu. Jansen Sinamo (Wahid, 2016) mendefinisikan etos kerja adalah seperangkat perilaku positif yang berakar pada keyakinan fundamental yang disertai komitmen total pada paradigma kerja yang integral. Etos kerja menurut Jansen Sinamo (Imam, 2013) terdiri dari beberapa aspek pengukuran meliputi: (1) Kerja adalah rahmat, (2) Kerja adalah amanah, (3) Kerja adalah panggilan, (4) Kerja adalah aktualisasi, (5) Kerja adalah ibadah, (6) Kerja adalah seni, (7) Kerja adalah kehormatan, (8) Kerja adalah pelayanan.Guru yang tidak memiliki etos kerja akan bekerja asal-asalan, sedangkan guru yang memiliki etos kerja yang baik akan bekerja penuh tanggung jawab dan pengabdian, karena pelaksanaan etos kerja merupakan upaya produktivitas kerja yang mendukung kualitas kerja.

Walaupun pemerintah telah berupaya sedemikian rupa untuk meningkatkan etos kerja guru, namun pada kenyataannya guru yang mempunyai berbagai karakteristik dan latar belakang tentunya belum semuanya dapat menyadari perlunya etos kerja. Sehingga tentunya masih ada beberapa guru yang kurang memiliki etos kerja. Oleh karena itu untuk menjadi seorang guru tidak mudah, untuk dapat melaksanakan tugas dan fungsinya dengan baik maka guru harus memiliki berbagai kompetensi. Penelitian ini terfokus pada manajemen kelas dan etos kerja guru tentang pengaruh manajemen kelas dan etos kerja terhadap efektivitas pembelajaran guru pada masa pandemi covid 19.

Rumusan masalah pada penelitian yaitu apakah terdapat pengaruh manajemen kelas terhadap efektivitas pembelajaran guru pada masa pandemi covid 19, apakah terdapat pengaruh etos kerja terhadap efektivitas pembelajaran guru pada masa pandemi covid 19, dan apakah terdapat pengaruh manajemen kelas dan etos kerja secara bersamaan terhadap efektivitas pembelajaran guru pada masa pandemi covid 19.Adapun tujuan dari penelitian yaitu untuk mengetahui pengaruh manajemen kelas terhadap efektivitas pembelajaran guru pada masa pandemi covid 19, untuk mengetahui pengaruh etos kerja terhadap efektivitas pembelajaran guru pada masa pandemi covid 19 dan untuk mengetahui pengaruh managemen kelas dan etos kerja secara bersamaan terhadap efektivitas pembelajaran guru pada masa pandemi covid 19.

Secara prinsip penelitian ini akan membawa manfaat bagi beberapa sektor, baik yang berkaitan langsung maupun tidak langsung antara lain manfaat teoritis hasil penelitian ini diharapkan berguna dalam pengembangan disiplin ilmu Manajemen Pendidikan serta memberikan penjelasan secara terperinci dan sistematis mengenai pengaruh manajemen kelas dan etos kerja terhadap efektivitas pembelajaran guru pada masa pandemi Covid 19. Manfaat praktis bagi kepala sekolah hasil penelitian ini dapat digunakan sebagai input bagi pimpinan dalam menentukan kebijakan-kebijakan yang berhubungan dengan kepemimpinan kepala sekolah dalam kaitannya dengan peningkatan etos kerja guru. Bagi guru dapat memberikan masukan untuk memahami kondisi real pekerjaan nya di lapangan, sebagai alat ukur dan evaluasi kinerja diri sendiri dan berupaya untuk bisa memberikan yang terbaik bagi diri dan lingkungan kerjanya. Bagi Peneliti hasil penelitian ini juga akan digunakan sebagai bahan pembelajaran dan memotivasi agar bisa melakukan hal yang lebih baik lagi bagi diri sendiri dan masyarakat. Batasan penelitian yaitu dilakukan terhadap guru Sekolah Dasar Negeri, 
1431 Pengaruh Manajemen Kelas Dan Etos Kerja Terhadap Efektivitas Pembelajaran Guru Pada Masa Pandemi Covid 19 - Pitriyani

DOI: https://doi.org/10.31004/edukatif.v3i4.587

fokus pada manajemen kelas dan etos kerja guru, dan objek yang diukur adalah efektivitas pembelajaran guru.

Menurut Moore D.Kenneth (Patmawati; Yunus, Muh; Devilla, Rego; Yahya, Muh, 2018) mendefinisikan efektivitas dengan ukuran yang menyatakan sejauh mana sasaran/ tujuan (kuantitas, kualitas, dan waktu) telah dicapai. Menurut Wotruba dan Wright (Nurlina, 2010) indikator yang dapat digunakan untuk menentukan efektivitas dalam proses pembelajaran adalah pengorganisasian materi yang baik, komunikasi yang efektif, penguasaan dan antusiasme terhadap materi pelajaran, sikap positif terhadap siswa, pemberian nilai yang adil, keluwesan dalam pendekatan pembelajaran, dan hasil belajar siswa yang baik. Adapun menurut Sudjana (Yusuf, Musyadad, Iskandar, \& Widiawati, 2021) kunci keberhasilan dalam pembelajaran terletak pada keterlibatan diri mereka dalam proses pembelajarannya. Proses pembelajaran dilaksanakan agar seseorang mempunyai pemahaman kognitif, psikomotorik, dan afektif sehingga akan lebih baik pada nantinya merupakan tujuan dari Pendidikan (Nurrohma \& Adistana, 2021)

Manajemen kelas didefinisikan sebagai seperangkat teknik dan keterampilan bagi guru untuk memberikan kontrol yang efektif untuk menghasilkan dan menciptakan lingkungan yang lebih baik untuk kegiatan pembelajaran (MoEC, 2013). Menurut Harsey (Nurlina, 2010) terdapat beberapa fungsi manajemen kelas yaitu perencanaan (planning) adalah merencanakan segala kegiatan dan aktivitas yang menyangkut penentuan tujuan-tujuan yang hendak dicapai selama masa yang akan datang dan apa yang harus diperbuat agar dapat mencapai tujuan-tujuan itu dengan tepat dan sesuai dengan harapan dan rencana yang telah ditetapkan. Pengorganisasian (organizing) artinya mengkoordinir pengelompokan dan menentukan serta memberikan kegiatan penting serta memberikan kekuasaan untuk melaksanakan kegiatan-kegiatan pada setiap bagian-bagian yang telah dibentuk lewat perencanaan yang telah diakomodir dengan rapi dan sistematis oleh setiap elemen pemegang kebijakan. Pelaksanaan (actuating) diartikan sebagai penggerakan dan bimbingan, merupakan aktifitas manajer alam memerintah, menugaskan, menjuruskan, mengarahkan,menuntun karyawan atau personel organisasi untuk melaksanakan pekerjaan-pekerjaan dalam mencapai tujuan yang telah ditentukan. Evaluasi (evaluation) adalah proses untuk mengukur kadar pencapaian tujuan. Ia lebih lanjut menjelaskan bahwa evaluasi yang bersinonim dengan penilaian tidak sama konsepnya dengan pengukuran dan tes meskipun ketiga konsep ini sering didapatkan ketika masalah evaluasi pendidikan dibicarakan.

Jansen Sinamo (Patmawati; Yunus, Muh; Devilla, Rego; Yahya, Muh, 2018) etos kerja adalah seperangkat perilaku positif yang berakar pada keyakinan fundamental yang disertai komitmen total pada paradigma kerja yang integral. Menurut Jansen Sinamo (Wahid, 2016) etos kerja terdiri dari beberapa aspek pengukuran meliputi kerja adalah rahmat, kerja adalah amanah, kerja adalah panggilan, kerja adalah aktualisasi, kerja adalah ibadah, kerja adalah seni, kerja adalah kehormatan, kerja adalah pelayanan.

Penelitian yang terdahulu yaitu oleh Ina Nurlina tentang pengaruh manajemen kelas dan etos kerja terhadap efektivitas proses belajar mengajar guru Sekolah Dasar di Kecamatan Babakan Cikao Kabupaten Purwakarta. Penelitian yang dilakukan oleh Patmawati, Muh Yunus, Rego Devilla, Muh. Yahya tentang pengaruh manajemen kelas dan etos kerja guru terhadap efektivitas pembelajaran Di SMP Negeri 1 Parepare. Penelitian yang dilakukan oleh Anjasari Erika tentang pengaruh manajemen kelas dan etos kerja guru terhadap efektivitas proses pembelajaran: Penelitian di SMP Negeri 1 Sukawangi-Kabupaten Bekasi. 
$\mathrm{X} 1$

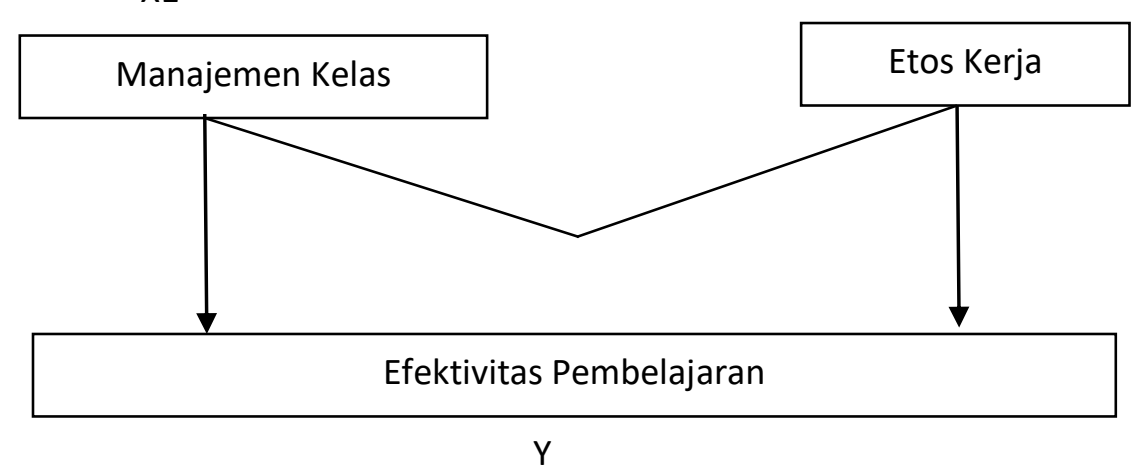

Gambar 1. Kerangka Pemikiran Penelitian

Adapun hipotesis dalam penelitian ini yaitu

$H_{0} \quad$ : Tidak Terdapat Pengaruh antara manajemen kelas dengan efektivitas pembelajaran guru di Sekolah Dasar

$H_{1} \quad$ : Terdapat Pengaruh antara manajemen kelas dengan efektivitas pembelajaran guru di Sekolah Dasar

$H_{0} \quad$ : Tidak Terdapat pengaruh antara etos kerja dengan efektivitas pembelajaran guru di Sekolah Dasar

$H_{1} \quad$ : Terdapat pengaruh antara etos kerja dengan efektivitas pembelajaran guru di Sekolah Dasar

$H_{0} \quad$ : Tidak Terdapat pengaruh antara manajemen kelas dan etos kerja secara bersamaan terhadap efektivitas pembelajaran guru di Sekolah Dasar.

$H_{1}$ : Terdapat pengaruh antara manajemen kelas dan etos kerja secara bersamaan terhadap efektivitas pembelajaran guru di Sekolah Dasar.

\section{METODE PENELITIAN}

Pendekatan yang digunakan dalam penelitian ini yaitu kuantitatif yang dimaksudkan untuk menjaring data hasil penelitian mengenai efektivitas pembelajaran. Rancangan penelitian yang digunakan yaitu survey dalam bentuk survey deskriptif. Menurut Arikunto (Yusuf, Musyadad, Iskandar, \& Widiawati, 2021) deskriptif yaitu mengumpulkan data sebanyak-banyaknya mengenai faktor-faktor yang merupakan pendukung terhadap penelitian.Penelitian ini dilaksanakan di 34 Sekolah Dasar Negeri di Kecamatan Jambi Luar Kota Kabupaten muaro Jambi provinsi Jambi. Anggota populasi yaitu keseluruhan guru kecamatan Jambi Luar Kota yang terdaftar pada data Dapodik Dinas Pendidikan Muaro Jambi Tahun 2021. Jumlah anggota populasi adalah 366 guru PNS dan 97 guru NON PNS. Penelitian dibatasi pada guru yang berstatus PNS terdiri dari 80 laki-laki dan 286 perempuan terbagi menjadi 34 sekolah.

Teknik pengambilan sampel pada penelitian ini mengunakan Teknik Probability sampling. Teknik Probability Sampling merupakan suatu teknik pengambilan sampel yang memberikan peluang yang sama pada setiap anggota populasi untuk dijadikan anggota sampel. Instrumen yang dipakai dalam penelitian ini yaitu kuesioner yang berfungsi untuk mendapatkan data manajemen kelas, etos kerja dan efektivitas. Data penelitian ini dikumpulkan dilakukan melalui kuesioner.

Pada penelitian ini peneliti memakai kuesioner pertanyaan tertutup, yaitu berupa serangkaian pertanyaan yang mengharapkan jawaban singkat atau mengharapkan responden untuk memilih salah satu alternative jawaban dari setiap pertanyaan yang telah disediakan oleh peneliti (Dantes \& Nyoman, 2012). Bagian item angket mengunakan angket adopsi memakai skala likert kisaran 1-5 dengan alternatif pilihan jawaban selalu (ss), sering (sr), kadang-kadang (kk), jarang (jr) tidak pernah (Patmawati; Yunus, Muh; Devilla, Rego; Yahya, Muh, 2018). 
Kisi-kisi instrument pada penelitian ini terdiri dari variabel efektivitas pembelajaran, manajemen kelas dan etos kerja. Jumlah responden yang diuji coba pada penelitian ini sebanyak 35 guru di Sekolah Dasar Negeri di Kecamatan Sekernan. Uji coba diperlukan untuk mengetahui apakah kuesioner yang digunakan dalam penelitian layak digunakan. Untuk mengukur validitas dan reliabilitas instrument angket per item atau butir soal peneliti mengunakan bantuan computer dengan program SPSS versi 22.

Uji normalitas dilakukan mengunakan teknik uji Lilierfor atau dalam program SPSS disebut dengan Kolmogrof-Smirnov. Berdasarkan hasil uji normalitas diketahui nilai signifikansi sebesar $0.143>0.05$ maka dapat disimpulkan bahwa nilai residual berdistribusi normal. Adapun hasil uji linearitas dan keberartian regresi linier yang dilakukan dengan mengunakan alat bantu SPSS versi 22. Berdasarkan nilai signifikansi (sig) diperoleh nilai Deviation from Linearity Sig. adalah $0.570>0.05$ maka dapat disimpulkan bahwa ada hubungan linear secara signifikan antara variable manajemen kelas (X1) dengan variable efektivitas pembelajaran $(\mathrm{Y})$.

\section{HASIL DAN PEMBAHASAN PENELITIAN}

Secara keseluruhan berdasarkan angket yang telah peneliti kelolah sebagaimana dilihat dari hasil kuesioner yang diisi oleh responden dengan jumlah total responden 191 orang guru di Kecamatan Jambi Luar Kota tergolong dalam kategori sangat tinggi. Hal ini bisa diasumsikan bahwa guru telah melaksanakan manajemen kelas dengan baik. Adapun menurut Harsey (Nurlina, 2010) ada empat fungsi manajemen kelas yaitu perencanaan (planning), pengorganisasian (organizing), pelaksanaan (actuating), dan evaluasi (evaluation).Dari temuan ini peneliti menyatakan bahwa diperkaya dengan analisis pembahasan instrument nilai rata-rata indicator manajemen kelas pada perencanaa (planning) sebesar 930.5 kategori sangat tinggi. Menurut Faizal (Wahid, 2016) perencanaan (planning) artinya merencanakan segala kegiatan dan aktivitas yang menyangkut penentuan tujuan-tujuan yang hendak dicapai selama masa yang akan datang dan apa yang harus diperbuat agar dapat mencapai tujuan-tujuan itu dengan tepat dan sesuai dengan harapan dan rencana yang telah ditetapkan. Nilai rata-rata indicator manajemen kelas pada pengorganisasian (organizing) sebesar 884 kategori sangat tinggi. Adapun menurut (Euis, 2015) organizing artinya mengkoordinir pengelompokan dan menentukan serta memberikan kegiatan penting serta memberikan kekuasaan untuk melaksanakan kegiatan-kegiatan pada setiap bagian-bagian yang telah dibentuk lewat perencanaan yang telah diakomodir dengan rapi dan sistematis oleh setiap elemen pemegang kebijakan. Nilai rata-rata indicator manajemen kelas pada pelaksanaan (actuating) sebesar 927.5 kategori sangat tinggi.

Menurut The Liang Gie (Patmawati; Yunus, Muh; Devilla, Rego; Yahya, Muh, 2018) pelaksanaan (actuating) yang diartikan sebagai penggerakan dan bimbingan, merupakan aktifitas manajer alam memerintah, menugaskan, menjuruskan, mengarahkan,menuntun karyawan atau personel organisasi untuk melaksanakan pekerjaan-pekerjaan dalam mencapai tujuan yang telah ditentukan. Nilai rata-rata indicator manajemen kelas pada evaluasi (evaluation) sebesar 922.5 kategori sangat tinggi. Suharsimi dan Arikunto (Wiyani \& Ardy, 2013) menyatakan bahwa setiap kegiatan evaluasi atau penilaian merupakan suatu proses yang sengaja direncanakan untuk memperoleh data sebagai dasar untuk membuat keputusan.

Manajemen kelas yang terdiri dari 4 indikator meliputi perencanaan (Planning), Pengorganisasian (Organizing), Pelaksanaan (Actuating), dan Evaluasi (Evaluation). Maka dapat dilihat bahwa rata-rata keseluruhan ke empat indicator sebesar 916 berada pada kategori sangat tinggi. Dapat disimpulkan bahwa guru di Sekolah Dasar Negeri Kecamatan jambi Luar Kota sudah melaksanakan manajemen kelas sesuai dengan fungsinya. Selanjutnya penelitian ini juga sejalan dengan temuan yang dikemukakan oleh peneliti lain (Nurlina, 2010) bahwa terdapat pengaruh manajemen kelas terhadap efektivitas pembelajaran.

Guru telah melaksanakan etos kerja sesuai dengan aspek-aspek pengukurannya. Adapun menurut Jansen Sinamo (Patmawati; Yunus, Muh; Devilla, Rego; Yahya, Muh, 2018) aspek-aspek pengukuran etos kerja yaitu kerja adalah rahmat, kerja adalah amanah, kerja adalah panggilan, kerja adalah aktualisasi, kerja adalah 
1434 Pengaruh Manajemen Kelas Dan Etos Kerja Terhadap Efektivitas Pembelajaran Guru Pada Masa Pandemi Covid 19 - Pitriyani

DOI: https://doi.org/10.31004/edukatif.v3i4.587

ibadah, kerja adalah seni, kerja adalah kehormatan dan erja adalah pelayanan.

Dari temuan ini peneliti menyatakan bahwa diperkaya dengan analisis pembahasan instrument nilai rata-rata pada indicator kerja adalah rahmat sebesar 931.5 kategori sangat tinggi. Nilai rata-rata pada indicator kerja adalah amanah sebesar 924.5 kategori sangat tinggi. Nilai rata-rata pada indicator kerja adalah panggilan sebesar 918 kategori sangat tinggi. Nilai rata-rata pada indicator kerja adalah aktualisasi sebesar 915 kategori sangat tinggi. Nilai rata-rata pada indicator kerja adalah ibadah sebesar 930 kategori sangat tinggi. Nilai ratarata pada indicator kerja adalah seni sebesar 890.5 kategori sangat tinggi. Nilai rata-rata pada indicator kerja adalah kehormatan sebesar 826 kategori sangat tinggi, dan nilai rata-rata pada indicator kerja adalah pelayanan sebesar 922.5 kategori sangat tinggi.

Variable etos kerja yang terdiri dari 8 indikator meliputi kerja adalah rahmat, kerja adalah amanah, kerja adalah panggilan, kerja adalah aktualisasi, kerja adalah ibadah, kerja adalah seni, kerja adalah kehormatan, kerja adalah pelayanan. Maka dapat dilihat bahwa rata-rata keseluruhan ke delapan indicator sebesar 920 berada pada kategori sangat tinggi. Dapat disimpulkan bahwa guru di Sekolah Dasar Negeri Kecamatan jambi Luar Kota sudah melaksanakan etos kerja sesuai dengan aspek pengukurannya. Selanjutnya penelitian ini juga sejalan dengan temuan yang dikemukakan oleh peneliti lain yaitu (Nurlina, 2010) tentang pengaruh manajemen kelas dan etos kerja guru Sekolah Dasar di Kecamatan Babakancikau Kabupaten Purwakarta bahwa terdapat pengaruh etos kerja terhadap efektivitas pembelajaran.

Guru telah melaksanakan efektivitas pembelajaran sesuai dengan indikator untuk menentukan efektivitas dalam proses pembelajaran. Adapun menurut Wotruba dan Wright (Nurlina, 2010) indikator yang dapat digunakan untuk menentukan efektivitas dalam proses pembelajaran adalah pengorganisasian materi yang baik, komunikasi yang efektif, penguasaan dan antusiasme terhadap materi pelajaran, sikap positif terhadap siswa, pemberian nilai yang adil, keluwesan dalam pendekatan pembelajaran, dan hasil belajar siswa yang baik.

Dapat dilihat nilai rata-rata pengorganisasian materi yag baik sebesar 933.5 kategori sangat tinggi. Nilai rata-rata komunikasi yang efektif sebesar 929 kategori sangat tinggi. Nilai rata-rata penguasaan dan antusiasme terhadap materi pelajaran sebesar 919 kategori sangat tinggi. Nilai rata-rata sikap positif terhadap siswa sebesar 923 kategori sangat tinggi. Nilai rata-rata pemberian nilai yang adil sebesar 916.5 kategori sangat tinggi. Nilai rata-rata keluwesan dalam pendekatan pembelajaran sebesar 914.5 kategori sangat tinggi, dan nilai rata-rata hasil belajar siswa yang baik sebesar 952.5 kategori sangat tinggi.

Variable efektivitas pembelajaran yang terdiri dari 7 indikator meliputi pengorganisasian materi yang baik, komunikasi yang efektif, penguasaan dan antusiasme terhadap materi pelajaran, sikap positif terhadap siswa, pemberian nilai yang adil, keluwesan dalam pendekatan pembelajaran, dan hasil belajar siswa yang baik. Maka dapat dilihat bahwa rata-rata keseluruhan ke tujuh indicator sebesar 927 berada pada kategori sangat tinggi. Dapat disimpulkan bahwa guru di Sekolah Dasar Negeri Kecamatan jambi Luar Kota sudah melaksanakan efektivitas pembelajaran sesuai dengan indikator untuk menentukan efektivitas dalam proses pembelajaran.

Variable manajemen kelas (X1) berpengaruh dan signifikan terhadap efektivitas pembelajaran di Sekolah Dasar Negeri Kecamatan Jambi Luar Kota. Hal ini dapat dilihat dari nilai signifikansi manajemen kelas $(\mathrm{X} 1) 0.00<0.05$. dan nilai ttabel $=(\alpha / 2 ; \mathrm{n}-\mathrm{k}-1=\mathrm{t}(0.05 / 2 ; 191-2-1)=(0.025 ; 188)=1.972$ berarti nilai thitung lebih besar dari ttabel $(9.023>1.972)$. Maka H0 ditolak dan H1 diterima, sehingga hipotesis yang berbunyi terdapat pengaruh manajemen kelas terhadap efektivitas pembelajaran diterima. Selanjutnya penelitian ini juga sejalan dengan temuan yang dikemukakan oleh peneliti lain (Nurlina, 2010) tentang pengaruh manajemen kelas dan etos kerja guru Sekolah Dasar di Kecamatan Babakancikau Kabupaten Purwakarta. Bahwa variable manajemen kelas berpengaruh dan signifikan terhadap variable efektivitas pembelajaran.

Variable etos kerja (X2) berpengaruh dan signifikan terhadap efektivitas pembelajaran di Sekolah Dasar 
Negeri Kecamatan Jambi Luar Kota. Hal ini dapat dilihat dari nilai signifikansi etos kerja (X2) $0.003<0.05$. dan nilai ttabel $=(\alpha / 2 ; \mathrm{n}-\mathrm{k}-1=\mathrm{t}(0.05 / 2 ; 191-2-1)=(0.025 ; 188)=1.972$ berarti nilai thitung lebih besar dari ttabel (3.007 > 1.972). Maka H0 ditolak dan H1 diterima, sehingga hipotesis yang berbunyi terdapat pengaruh etos kerja terhadap efektivitas pembelajaran diterima. Selanjutnya penelitian ini juga sejalan dengan temuan yang dikemukakan oleh peneliti lain (Nurlina, 2010) tentang pengaruh manajemen kelas dan etos kerja guru Sekolah Dasar di Kecamatan Babakancikau Kabupaten Purwakarta. bahwa variable etos kerja berpengaruh dan signifikan terhadap Variabel efektivitas pembelajaran.

Variable manajemen kelas (X1) dan etos kerja (X2) secara bersamaan berpengaruh signifikan terhadap efektivitas pembelajaran di Sekolah Dasar Negeri Kecamatan Jambi Luar Kota Dapat diketahui bahwa nilai Fhitung sebesar 5.169 dengan besar nialai Ftabel adalah 3.04 sehingga nilai Fhitung > nilai Ftabel atau 5.169 $>3.04$ dan tingkat signifikan $0.007<0.05$ maka H0 ditolak dan H3 diterima. Selanjutnya penelitian ini juga sejalan dengan temuan yang dikemukakan oleh peneliti lain (Nurlina, 2010) tentang pengaruh manajemen kelas dan etos kerja guru Sekolah Dasar di Kecamatan Babakancikau Kabupaten Purwakarta. bahwa variable manajemen kelas, variable etos kerja secara bersamaan berpengaruh dan signifikan terhadap Variabel efektivitas pembelajaran.

Temuan penelitian ini memberikan gambaran nyata bahwa variable yang diteliti yaitu manajemen kelas dan etos kerja baik secara terpisah maupun secara simultan memiliki hubungan yang signifikan terhadap efektifitas pembelajaran. Berdasarkan temuan tersebut makna sumbangan terhadap ilmu pengetahuan yaitu bagi guru disarankan untuk berusaha meningkatkan pengelolaan kelas sesuai dengan disiplin profesionalisme guru dalam pembelajaran. Hal tersebut tercermin dalam pelaksanaan pembelajaran dan hubungan social antara guru dengan siswa. Menumbuhkan dan meningkatkan keterbukaan mengenai kelebihan dan kelemahan yang dimiliki dalam menjalankan tugas dan pembuatan perangkat pembelajaran. Berusaha menciptakan iklim kerja yangyang nyaman dengan rekan kerja maupun dengan atasan baik secara fisik maupun secara psikologis agar tercermin suasana yang aman dan nyaman dalam bekerja.

\section{KESIMPULAN}

Berdasarkan hasil penelitian dan pembahasan yang telah diuraikan pada bab sebelumnya, hasil dari penelitian dan pengujian yang dilakukan terhadap pengaruh manajemen kelas dan etos kerja terhadap efektivitas pembelajaran di Sekolah Dasar negeri kecamatan Jambi Luar Kota maka dapat diambil kesimpulan berdasarkan hasil analisis pengujian yang dilakukan maka dapat disimpulkan bahwa terdapat pengaruh manajemen kelas terhadap efektivitas pembelajaran di Sekolah Dasar Negeri Kecamatan Jambi Luar Kota, terdapat pengaruh etos kerja terhadap efektivitas pembelajaran di Sekolah Dasar Negeri Kecamatan Jambi Luar Kota, dan terdapat pengaruh manajemen kelas dan etos kerja terhadap efektivitas pembelajaran di Sekolah Dasar Negeri Kecamatan Jambi Luar Kota.

\section{UCAPAN TERIMA KASIH}

Alhamdulillah atas berkat Rahmat Allah Swt SWT. Akhirnya penulis dapat menyelesaikan penelitian ini sehingga dapat diselesaikan dan dilaporkan secara tertulis. Perkenankanlah penulis menyampaikan maksud hati ucapan terima kasih yang sebesar-besarnya dan penghargaan yang setinggi-tingginya terutama kepada Yth. Ibu Dr. Drs. Hj. Muazza, M. Si selaku dosen pembimbing I, ditengah-tengah kesibukannya masih dapat menyempatkan diri untuk membimbing penulis, memberikan petunjuk dan arahan. Terima kasih kepada Bapak Dr. K.A. Rahman, M. Pd. I selaku dosen pembimbing II ditengah-tengah kesibukan masih bisa meluangkan waktunya guna membimbing penulis. Terima kasih kepada abang Hendri Azzambi, S. Pd. I yang selalu sabar dan selalu bersedia meluangkan waktunya dalam pengurusan administrasi. Terima kasih kepada Suami Muhamad Hamdi, M. Pd yang selalu membimbing agar menjadi manusia yang bergunana untuk banyak orang. Terima kasih untuk anakku tercinta Shelmagadiza yang selalu menghibur dengan tingkah lucu 
1436 Pengaruh Manajemen Kelas Dan Etos Kerja Terhadap Efektivitas Pembelajaran Guru Pada Masa Pandemi Covid 19 - Pitriyani

DOI: https://doi.org/10.31004/edukatif.v3i4.587

dan manisnya. Terima kasih kepada Almarhum bapak M. Soleh yang selalu memberi bimbingan dan motivasi terutama dalam menuntut ilmu. Terima kasih kepada mak Siti Ayu yang telah mengajarkan kesabaran, disiplin, dan kemandirian. Terima kasih kepada adikku Harmita yang telah mengajarkan berbakti kepada kedua orang tua. Terima kasih kepada bapak mertuaku H. Sargani, ibu mertuaku Hj. Jamalia, S. Pd, abang iparku Nagusliansyah, S. Pd. I, Nurwansyah, ayuk iparku Etty, adx iparku Riska Armely, keponakanku Alexandria, Uais Al-Qorni dan Ahmad Muafiq yang selalu mendukung dan selalu pengertian dalam segala kondisi keadaan.

\section{DAFTAR PUSTAKA}

Dantes, \& Nyoman. (2012). Metode Penelitian. Yogyakarta: Andi.

Djabidi, F. (2017). Manajemen Pengelolaan Kelas. Jakarta: Intrans Publishing.

Emmer, C. M. (2011). Manajemen Kelas Untuk Guru Sekolah Dasar. Jakarta: Kencana Prenada Media Group.

Euis, K. (2015). Manajemen Kelas Classroom Management. Bandung: Alfabeta.

Farel, G., Ambiyar, Simatupang, W., Giatman, M., \& Syahril. (2021). Analisis Efektivitas Pembelajaran Daring pada SMKdengan Metode Asynchronous dan Synchronous. EDUKATIF: JURNAL ILMU PENDIDIKAN, 3, 1185 - 1190. Retrieved from https://edukatif.org/index.php/edukatif/index

Imam, A. (2013). Pengelolaan kelas dari teori ke praktek. Yogyakarta: Insyira.

MoEC. (2013). Peraturan menteri pendidikan dan kebudayaan republik Indonesia nomor 65/2013 tentang standar proses pendidikan dasar dan menengah [The decree of the minister of education and culture no $65 / 2013$ on the standards for primary and middle education]. Jakarta: Kementerian Pendidikan.

Nurlina, I. (2010). Pengaruh Manajemen Kelas Dan Etos Kerja Terhadap Efektivitas Proses Belajar Mengajar Guru Sekolah Dasar Di Kecamatan Babakan Cikao Kabupaten Purwakarta. Jurnal Admisistrasi Pendidikan Universitas Pendidikan Indonesia, 12. Retrieved from https://ejournal.upi.edu/index.php/JAPSPs/article/view/6380/4338

Nurrohma, R. I., \& Adistana, G. A. (2021). Penerapan Model Pembelajaran Problem Based Learning dengan Media E-Learning Melalui Aplikasi. EDUKATIF: JURNAL ILMU PENDIDIKAN, 3(4), doi:https://doi.org/10.31004/edukatif.v3i4.544

Patmawati; Yunus, Muh; Devilla, Rego; Yahya, Muh. (2018). Pengaruh Manajemen Kelas Dan Etos Kerja Guru Terhadap Efektivitas Pembelajaran Di Smp Negeri 1 Parepare. Jurnal Ilmiah Pena Sains dan Ilmu Pendidikan, 10.

Pebrianto, Herpratiwi, \& Fitriawan, H. (2021). Pengembangan Multimedia Pembelajaran Hari Raya Agama Buddhadi Sekolah Minggu Buddhis Bodhisattva. EDUKATIF: JURNAL ILMU PENDIDIKAN, 3, 1261 - 1270. Retrieved from https://edukatif.org/index.php/edukatif/index

Suyono. (2012). Belajar dan Pembelajaran. Bandung: PT Remaja Rosdakarya.

Wahid, I. A. (2016). Pengaruh Motivasi, Etos Kerja Dan Disiplin Kerja Terhadap Kinerja Pegawai Negeri Sipil (Pns) Pada Dinas Kehutanan Dan Perkebunan Daerah Kabupaten Morowali. Jurnal Katalogis, Volume 4 Nomor 8, Agustus 2016 hlm 156-163, 4. Retrieved from https://media.neliti.com > media > publications

Wiyani, \& Ardy, N. (2013). Manajemen Kelas. Yogyakarta: Ar-Ruzz Media.

Yusuf, R. N., Musyadad, V. F., Iskandar, Y. Z., \& Widiawati, D. (2021). Implikasi Asumsi Konsep Diri Dalam Pembelajaran Orang Dewasa. Edukatif : Jurnal Ilmu Pendidikan, 3(4).

https://doi.org/10.31004/edukatif.v3i4.513 